\title{
ÉLETPÁLYA-TERVEZÉS SAJÁTOS NEVELÉSI IGÉNYÜ FIATALOK ESETÉBEN
}

\section{Szerzők:}

\author{
Mező Katalin (PhD.) \\ Debreceni Egyetem \\ (Magyarország)
}

Móré Mariann (PhD.)

Debreceni Egyetem

(Magyarország)

Első szerző e-mail címe:

kata.mezo1@gmail.com

\section{Lektorok:}

\author{
Bene Ágnes (PhD.) \\ Debreceni Egyetem \\ (Magyarország) \\ Mező Ferenc (PhD.) \\ Eszterházy Károly Katolikus Egyetem \\ (Magyarország)
}

...és további két anonim lektor

Mező Katalin, Móré Mariann (2021): Életpálya-tervezés sajátos nevelési igényű fiatalok esetében. Különleges Bánásmód, 7. (4). 21-30. DOI 10.18458/KB.2021.4.21

\begin{abstract}
Absztrakt
A tanulmány a sajátos nevelési igényű fiatalok életpálya-tervezésének megvalósítási lehetôségeit elemzi hazánkban. A téma kifejezetten aktuális, hiszen a szakképzés rendszerének hazai átalakítási folyamata (Szakképzés 4.0, 2020) során egyre inkább kirajzolódik, hogy a szakiskola elsődleges továbbtanulási célként jelenik meg a sajátos nevelési igényú tanulók egyes csoportjai számára. A szakiskolákban képzett szakemberek potenciális munkavállalóként jelenhetnének meg a munkaerőpiacon, mégsem történik meg minden esetben az akadálymentes és automatikus munkavállalás a középiskola elvégzése után. Az életpálya-tervezés - mely a sajátos nevelési igényú fiatalok esetében kiegészül és egybefonódik az Egyéni Átvezetési Terv készítésével - megoldást jelenthetne a vázolt problémára, ezért a jelen tanulmány célja, hogy felhívja a figyelmet e lehetőség tudatos és szakszerú alkalmazására a sajátos nevelési igényű fiatalok esetében is.
\end{abstract}

Kulcsszavak: életpálya-tervezés, szakképzés, sajátos nevelési igényű fiatalok, középiskola, Egyéni Átvezetési Terv

Diszciplína: pedagógia

\section{Abstract \\ CAREER PLANNING OF YOUNG PEOPLE WITH SPECIAL EDUCATIONAL NEEDS}

The study analyzes the possibilities of career planning of young people with Special Educational Needs in Hungary. This topic seems to be especially relevant, as the process of transforming the vocational education system in Hungary (Vocational Education 4.0, 2020) makes it even clearer that the vocational school appears to be the most achievable secondary educational goal for certain groups of students with Special Educational Needs. Skill workers trained in vocational schools could appear in the labor market as potential employees, however, partly because obstacle-free and automatic employment do not always happen after leaving secondary school. Career planning is a possible solution to the problem outlined. The career planning can be supplemented and intertwisted with the preparation of the Individual Transition 
Plan for young people with Special Educational Needs. Therefore, the purpose of the present study is to draw attention to the conscious and professional use of career planning of young people with SEN.

Keywords: career planning, vocational training, young people with Special Educational Needs, secondary school, Individual Transition Plan

Discipline: pedagogy

\section{Bevezetés}

A KSH 2021 júliusi adatai szerint a hazai aktív korú (15-74 éves) népesség körében a munkaerőpiacon foglalkoztatottak átlagos havi létszáma 4 millió 692 ezer fó volt, ami a korábbi évekhez képest ismételten egy kedvező irányba történő elmozdulást jelent (KSH, 2021, I1). A növekedés széles bázison nyugszik, de a legnagyobb mértékben a piaci alapú szolgáltatások járultak hozzá, melynek alapját a jól képzett, aktív humánerőforrás jelenti. A munkaerőpiaci aktivitás növelése egyaránt fontos célkitűzés az átlagos képességekkel és az átlagtól eltérő képességekkel rendelkező fiatalok esetében, mivel a munkahelyi elhelyezkedés tekinthetô a társadalmi integráció, a felnôtt lét és az életben való boldogulás bázisának.

Magyarországon az Innovációs és Technológiai Minisztérium felel a gazdaság folyamatainak irányításáért, mely egyben felel a szak- és felnőttképzésnek a gazdaság igényeihez igazodó vezetéséért is. $\mathrm{E}$ feladatában központi hivatalként támaszkodik a Nemzeti Szakképzési és Felnőttképzési Hivatalra. A Nemzeti Szakképzési és Felnőttképzési Hivatal feladatai között szerepel (319/2014. (XII. 13.) Korm. rendelet a Nemzeti Szakképzési és Felnőttképzési Hivatalról), hogy: 1) a gazdasági kamarával együttmúködve pályaorientációs rendszert (5§. 15.) alakít ki és múködtet; 2) kidolgozza és múködteti az életpálya-tanácsadási szolgáltatást, valamint 3) tovább-fejleszti és múködteti a pályakövetési rendszert (5§.16.). Ezzel együtt olyan életpálya-tervezéssel kapcsolatos feladatok ellátása is célként fogalmazódik meg, mely alkalmas az egész életen át tartó tanulás ösztönzésére a felnőtt lakosság esetében is.

Magyarországon az egész életen át tartó tanulásban résztvevô felnőttek aránya az EUROSTAT adatai szerint az EU tagállamok átlagánál némileg alacsonyabb, ezért az egész életen át tartó tanulás ösztönzése érdekében javítani szükséges a munkavállalói korban lévô népesség formális és informális képzési, kompetenciafejlesztési lehetőségekhez való hozzáférését. Már az EU2020 stratégiához kapcsolódó, szakpolitikai keretrendszerben (Európai Oktatás és Képzés 2020) is megfogalmazódott, hogy a tagállamoknak különösen a következő négy stratégiai célkitűzéssel kell foglalkozniuk:

1. Az egész életen át tartó, felnőttkori tanulás és a mobilitás megvalósítása.

2. Az oktatás és a képzés minőségének és hatékonyságának javítása.

3. A méltányosság, a társadalmi kohézió és az aktív polgári szerepvállalás előmozdítása a felnőttkori tanulás eszközeivel.

4. Az innováció és a kreativitás - a vállalkozói készségeket is beleértve - fejlesztése az oktatás és a képzés minden szintjén.

Az oktatás terén az EU célul tűzte ki, hogy 2020ra a tagállamokban a felnőttek - különösen az alacsony képzettségúek (köztük a sajátos nevelési igényúek) - egész életen át tartó tanulásban való részvételének aránya legalább a 15 \%-ot érje el. Ennek megvalósítása érdekében hazánkban több nagyszabású intézkedés végrehajtását tűzte ki célul (GINOP-6.2.4.-VEKOP/16 projekt): 1) A munkaerőpiaci igényekhez rugalmasan alkalmazkodni képes oktatási és képzési rendszerek kialakítása. 2) A tanulásból a munkába történő átmenet megkönnyítése. 3) A szakmai képzési rendszer szervezeti megerősítése és minőségének javítása többek között a szakképzési rendszer 21. századi múködéséhez szükséges intelligens irányítási keretrendszerének kialakítása. 4) A tanulást meghatározó környezet és szakmai tartalom keretrendszerének 
kialakítása. 5) A munkaalapú tanulási rendszerek beleértve a duális tanulási rendszereket és a tanulószerződéses gyakorlati képzéseket - hatékonyabbá tétele.

2020 januárjától (az új Szakképzésről szóló 2019. évi LXXX. törvény bevezetésével) hazánkban is megkezdődött a középszintû szakképzés radikális átalakítása, mely természetszerűen érintette a sajátos nevelési igényú fiatalok középfokú továbbtanulását, szakiskolai képzését is. Az átalakulás legfőbb célja a magas színvonalú, a munkaerőpiaci igényekhez és elvárásokhoz jobban igazodó, új szemléletű oktatási rendszer kialakítása, s deklarált célként szerepel a hátránykompenzáció és az iskolai lemorzsolódás csökkentése is. Az átalakulás folyamatban van, számos változtatás, módosítás várható a teljes rendszer kiépüléséig. Ezekben a változásokban benne rejlik a sajátos nevelési igényű fiatalok egész életen át tartó tanulását elősegítő pozitív változások lehetősége is, melynek megvalósításához többek között az életpálya-tervezés rájuk vonatkozó kiterjesztésére és átgondolására is szükség van.

Jelen tanulmányban a sajátos nevelési igényú fiatalok egész életen át tartó tanulását elősegítő életpálya-tervezésének szükségességére szeretnénk felhívni a figyelmet, mivel a jelenleg megvalósuló, a tervezést, az előre látást többnyire nélkülöző pályaválasztás (melyben többnyire a Pedagógiai Szakszolgálatok döntése a meghatározó, az egyéni érdeklődésen alapú döntések helyett) nem segíti elő az érintettek továbbtanulási ösztönzését és sajnos gyakran a munkaerőpiacon való elhelyezkedését sem.

\section{Elméleti megközelítés}

A 21. századra jellemző a munka és a tanulás rendszerének jelentôs mértékú átalakulása, amely kihívást állít az egyének elé, s az egyéni életpálya folyamatos átgondolását, tervezését követeli. Borbély-Pecze (2017) tanulmányában az egyéni életpályában megjelenő változásokra hívja fel a figyelmet, melyet a VUCA (volatility, uncertainty, complexity, ambiguity) mozaikszóban összegez. A VUCA magában foglalja a volatilitást, változékonyságot; a bizonytalanságot; a komplexitást, a kettősséget, kétértelmúséget. A jelenség, olyan helyzetek leírására vonatkozik, amikor minden kiszámíthatatlan és szinte bármi megtörténhet a cselekmény szerepelőivel (Stiehm, 2002). Ez a nagyfokú bizonytalanság és átmeneti jelleg határozza meg az egyéni életpályát és karriert is.

Napjainkban a pályaválasztás nem egyszeri, életre szóló döntésfolyamat, hanem változó folyamatok összessége. A pályaválasztási döntéseknek - az isko-laválasztáshoz kapcsolódó első és későbbi döntéseknek, a szakmai életutat meghatározó tovább-képző és/vagy pályamódosító döntéseknek - sors-fordító szerepe van az egyén életében. A döntések meghatározzák az egyén munkaerőpiaci helyzetét, karrierjének sikerét és befolyásolják a személyes és szociális kapcsolatainak életminőségét is. A döntési folyamat nem egyszerú, éppen ezért szükség van olyan, professzionális életpálya-tervezési rendszer kialakítására, mely elősegíti a megalapozott, az egyén és a társadalom szempontjából is előnyös döntési folyamat véghezvitelét.

Kutatási tapasztalatok (Mihály, 2000; Kálmán, 2017; Hegyi-Halmos, 2017) azt mutatják, hogy a munkaerôpiac jelentős mértékben átalakult. Amíg a 20. századi foglalkoztatásra az volt a jellemző, hogy a megszerzett szaktudás akár egy életen át megfelelt a viszonylag állandó munkaerôpiaci követelményeknek, addig a globalizáció, a folyamatos technológiai változások és az ezek alapján folyamatosan változó munkaszervezeti keretek, olyan helyzeteket teremtenek, ahol a pálya kiválasztása - és ezzel a belépés a munkaerôpiacra - már semmilyen garanciát nem jelentenek a késóbbi biztos megélhetésre vagy státuszfenntartásra. Mindez azt is magával hozza, hogy a fiatalokat és felnőtteket fel kell készíteni a munkahelyváltásra, a pályamódosításokra valamint a szaktudás gyors elévülésére.

Emellett a munkaerôpiac is radikális változáson megy keresztül, többek között a megállíthatatlan technikai fejlődésnek köszönhetően. A digitalizáció új kompetenciák megjelenését kívánja a munkaerőpiacon megjelenő felnőtt lakosságtól. A digitális kompetencia ma már nemcsak az infokommunikációs technológiákhoz való hozzáférést jelenti, hanem azok használatát, a használathoz 
kapcsolódó megfelelő ismereteket, készségeket és attitűdöket is magába foglalja. Vuorikari (2014) a teljes Európai Unióra kiterjedő 2014-ben elvégzett, s a digitális befogadásról és készségekről szóló kutatása alapján megállapította, hogy az unió népessége közel 47\%-ának elégtelenek a digitális kompetenciái (köztük vannak azok is - $23 \%$-, akik semmilyen digitális kompetenciával nem bírnak).

A gyorsan változó kulturális környezetben a versenyképes tudás fenntartása csak a folyamatos, egész életen át tartó, a felnőtt életet végig kísérő tanulás révén lehetséges. Az élethosszig tartó tanulás járulhat hozzá ahhoz, hogy az egyén képessé váljon megbirkózni a változó munkaerőpiaci kihívásokkal és biztosított legyen a folyamatos foglalkoztatása. Azonban ez nem minden felnőtt esetében egyértelmú, különösen nem a sajátos nevelési igényú fiatalok esetében, mivel számos új kompetencia meglétét feltételezi. Ennek eredményeként és elősegitése érdekében, az egész életen át tartó tanulás (lifelong learning, LLL) koncepciójához illeszkedve az Európai Unión belül és az OECD-országok egy részében az egész életen át tartó tanulás paradigmájának meghatározó elemévé vált az új felfogású életút-támogató pályaorientációs tevékenység, rendszer és szakpolitika (lifelong guidance, LLG), mely leginkább hasonul az életpályatervezési folyamatokhoz (az óvodától a szakmai életút végéig).

\section{Az életpálya-tervezéssel kapcsolatos alap- fogalmak}

A fogalomhasználatban az Európai Pályaorientációs Szakpolitikai Hálózat (European Lifelong Guidance Policy Network, ELGPN) által összeállított Szakszótárra (2011) hagyatkozunk. E szerint az életpálya (Career): egy személy életén átívelő munkahelyi szerepek és egyéb életszerepek egymásra gyakorolt hatása, beleértve, hogy az adott személy miként találja meg az egyensúlyt a fizetett és fizetetlen munkafeladatai között, valamint mennyi idôt és energiát szán tanulásra és továbbképzésre.

Az életpálya-tervezés fogalma nem jelenik meg az ELGPN glosszáriumában. Az életpálya-tervezés leginkább az életút-támogató pályaorientációs tevékenységhez (lifelong guidance, LLG) hasonul. „Az LLG, vagyis az életút-támogató pályaorientáció „olyan tevékenységek összessége, amelyek bármilyen korosztályhoz tartozó állampolgárok számára, életük bármely pontján lehetôvé teszik, hogy felmérjék képességeiket, kompetenciáikat és érdeklődésüket; hogy észszerū oktatási, képzési és foglalkoztatási döntéseket hozzanak, valamint, hogy menedzselni tudják egyéni életútjukat a tanulás, munka és egyéb olyan területeken, ahol ezeket a képességeket és kompetenciákat sajátíthatják el vagy használhatják" (Európai Pályaorientációs Szakpolitikai Hálózat Szakszótára, 2011, 13.).

Hazánkban több meghatározás is érthető rajta (Mező, 2021): pályafejlődési tanácsadás (Ritoókné, 2008), életpálya-tanácsadás (Borbély-Pecze, 2010b), életút-támogató pályaorientáció (Borbély-Pecze, 2010a), pályatervezés (Szilágyi, 2000).

Az életút-támogató pályaorientáció széleskörű: 1) magában foglalja az egyéni életpálya-építési kompetenciák (career management skills, CMS) kialakítását és alkalmazására való felkészítést (Sultana, 2011; ELGPN, 2012), 2) magában foglalja az ehhez kapcsolódó humán szolgáltatásokat és szakemberek szakmai kompetenciáit, felkészitését (Szilágyi, 2000); végül 3) tartalmaz egy olyan szakpolitikai rendszert is (Borbély-Pecze, 2010), mely gyakorlati kereteket biztosít az életút-támogató pályaorientáció megvalósításhoz.

Az egyéni életpálya sikeres és folyamatos alakításához, tervezéséhez megfelelő tudásra és készségekre van szükség. E készségeket és ismereteket összefoglaló néven életpálya-építési kompetenciáknak (career management skills, CMS) nevezzük. $\mathrm{Az}$ életpálya-építési kompetenciák „megszerzése képessé teszi az egyént arra, hogy összegyújtsön, értelmezzen és szintetizáljon önismereti, oktatási és munkaerő-piaci információkat, valamint arra, hogy e szintézis alapján pályatervet készítsen, vizsgáljon felül vagy valósítson meg” (Sultana, 2011).

$\mathrm{Az}$ életpálya-építési kompetenciákat BorbélyPecze, Gyöngyösi és Juhász (2013) a következőképp foglalják össze:

- a szakmai pályák, a munka világának ismerete, az abban való eligazodáshoz, az álláskereséshez 
és munkahely-megtartáshoz szükséges készségek;

- az önismeret és a képesség az önismeret és a pályák világának összekötésére, az öndefiníció (Super, 1980) kialakulása és folyamatos felülvizsgálata, átültetése egy pályaképbe, a saját pályaterv megvalósításához szükséges tanulási utak, képzési lehetőségek ismerete;

- képesség a képzési, munkaerőpiaci, társadalmi információk megszerzésére, értelmezésére, a döntések előkészítésére, valamint a döntések és a változások következményeinek kezelésére.

Az életpálya-tervezés meghatározására Kenderfi (2011) vállalkozott: „Az életpálya-tervezés olyan tevékenység, amely biztosítja az egyén számára, hogy lehetőségeinek megfelelően, tudatosan, tervszerúen alakítsa sorsát. E tevékenység keretében életpálya-célokat tűz ki, stratégiát készít a célok eléréséhez, majd az életpálya-építés során megvalósítja azt. A tervezés akkor sikeres, ha a célkitűzés reális, azaz a megvalósításhoz szükséges feltételrendszer rendelkezésre áll, vagy megteremthetó, illetve ha az utak és stratégiák alkalmasak a célok eléréséhez".

Az Európai Unió ajánlásában számos olyan dokumentum született, melyek olyan irányelveket, javaslatokat fogalmaznak meg, amelyek hatással vannak az életpálya-tervezés kérdéskörére (lásd. Tanítani és tanulni - A tanuló társadalom felé. Az oktatás fehér könyve, 1995; Memorandum, 2000; Oktatás és képzés, 2010; Oktatás és képzés, 2020; Európa, 2020.).

A Lifelong Learning stratégiában (European Area of Lifelong Learning, 2001) az Unió célul túzte ki a pályaorientációt, melyet, mint az életút során egymást követő pályaváltások sikeres megoldását segítő, támogató rendszerként jelenítenek meg. Ennek egyik legjelentôsebb vívmánya a lifelong learning stratégia (European Area of Lifelong Learning - A Bizottság közlemé-nye, 2001. november 21., az egész életen át tartó tanulás európai térségének megvalósításáról). Az életút-támogató pályaorientáció az élethosszig tartó tanulás szemléletével együtt terjed el. A lifelong learning-szemléletben az egyén egész életútját tanulás jellemzi, melynek segítségével képessé válik a gyorsan változó munkaerôpiaci elvárásokhoz való alkalmazkodásra. Az életpálya-tervezés segítséget nyújt az egyén számára a képzési, munkaerőpiaci döntéseinek meghozásában, az életpálya-építési kompetenciáinak fejlesztésében, s lehetóséget biztosít a felmerülő döntési pontokon tanácsadás igénybevételére. A pályaorientáció, életpálya-tervezés és pályatanácsadás meghatározó szerepúvé vált a későbbiekben megjelenő dokumentumokban is (Oktatás és képzés, 2010; Oktatás és képzés, 2020; Európa, 2020.).

A Lisszaboni Stratégia céljainak elérése érdekében született 2004-es közösségi döntés előírta minden tagállam számára a nemzeti és európai pályaorientációs rendszerek fejlesztését. Ennek koordinálása érdekében 2007-ben megalakult az Európai Pályaorientációs Szakpolitikai Hálózat (ELGPN) azzal a céllal, hogy segítse az Európai Unió (EU) tagállamai (illetve az EU élethosszig tartó tanulási programjába való becsatlakozásra jogosult szomszédos államok) és az Európai Bizottság között az európai pályaorientációs együttmúködés fejlesztését mind az oktatási, mind pedig a foglalkoztatási szektorban. A szervezet célja, hogy elősegítse a tagállami szintủ együttmúködést az EU Pályaorientációs Határozatai $(2004,2008)$ által megállapított prioritások végrehajtása során. E prioritások a következők:

- Karrier-, életpálya-menedzselési kompetenciák, skillek fejlesztése minden uniós állampolgár számára.

- A pályaorientációs szolgáltatásokhoz történő hozzáférés szélesítése (access).

- Szakpolitikai és intézményközi koordinációs mechanizmusok kialakítása nemzeti szinten.

- A pályaorientációs szolgáltatások minőségbiztosításának és monitoringjának megvalósítása.

Az ELGPN 2013-ban fontosnak tartotta az életpálya-vezetési készségek (Career Management Skills, CMS) fogalmának meghatározását. „Az életpálya-vezetési készségek, olyan kompetenciák körére vonatkoznak, melyek strukturált módon biztosítják az egyének és csoportok számára, hogy 
összegyúijtsék, elemezzék, szintetizálják és szervezzék az információkat önmagukról, az oktatásról és foglalkoztatásról, valamint a döntéshozatalhoz és az átmenetekhez kapcsolódó készségekről."”

Az életpálya-vezetési készségek fejlesztésének két úton képzelték el: 1) életpálya-építési ismeretek oktatása, mint az életpálya-vezetési készségek fejlesztésére kifejezetten koncentráló oktatási tevékenység. Ennek a forgatókönyvnek a fő jellemzői: a formális tanulási folyamat egységessége; egyértelmú fókusz az életpálya elômozdítása szempontjából fontos képességek rendszerére; a tanulási tevékenységek fejlesztésére használt életpálya-vezetési készségek egységes struktúrája; illetve az életpályavezetési készségek, mint a tervezett tanulási tevékenység világosan meghatározott és mért kimenetei. 2) Az életpálya-vezetési készségek fejlesztéséhez közvetve kapcsolódó tevékenységek. Ezeknek a forgatókönyveknek a fó jellemzői: a szervezett tevékenység (tanulási tapasztalat vagy pályaorientáció) általános céljai szélesebb körűek, mint az életpálya fejlesztéséhez fontos készségek, habár a tevékenység bizonyos kimenetei az életpálya-vezetési készségek közé sorolhatók. Ezen lehetséges forgatókönyvön belül két lehetséges tevékenység jelenik meg. Egyrészt a tanulási tapasztalat (formális, nem-formális, informális). Másrészt a pályaorientációs szolgáltatások és tanácsadással kapcsolatos tevékenységek.

Az Európai Pályaorientációs Szakpolitikai Hálózat az Európa 2020 stratégiában szerepló munkaügyi és oktatási szakpolitikákat figyelembe véve fejleszti a pályaorientáció rendszerét. Mivel az életpálya-tanácsadást szakpolitikákon átívelő és egész életen át tartó folyamatként értelmezik, a Hálózat az életpálya-tanácsadás szakpolitikáját a közoktatás, a szakképzés, a foglalkoztatás, a felsőoktatás és a felnőttoktatás szektorának bevonásával képzeli el (Garay, 2013).

\section{Életpálya-tervezés sajátos nevelési igényü fiatalok esetén}

A sajátos nevelési igényú fiatalok életpályatervezésének alapja az Egyéni Átvezetési Terv alkalmazása, mely átíveli az életkorokat és összefüg- gésbe hozza az egyén képességeit, nézeteit, érdeklődési körét és kompetenciáit a későbbi munkaerőpiaci elvárásokkal. Az Egyéni Átvezetési Terv (EÁT) a sajátos nevelési igényú tanulók iskolából a munka világába való átvezetését segítő stratégiai elképzelés (Soriano, 2005), melynek megvalósítása a feledés homályába merült, holott a benne foglaltak valós segítséget nyújthatnának a szakiskolát elvégző fiatalok és családtagjaik számára.

Az Egyéni Átvezetési Terv „olyan eszköz, egy dokumentum formájában, amelyben a fiatal múltját, jelenét és kívánt-elképzelt jövőjét jegyzik fel és dokumentálják (...) Az EÁT keretet ad, amely azt célozza, hogy a munkaerôpiacra történő belépés körülményei minél kedvezőbbek legyenek. Dinamikus folyamatot jelent, amely a következőkre terjed ki: 1) a fiatalok jellemző vonásai (készségek, képességek, kompetenciák és elvárások); 2) a foglalkoztatási szektor igényei és követelményei, valamint; 3) egy akcióterv állandó revíziója" (Soriano, 2005, 24.).

Az Egyéni Átvezetési terv célja, hogy a sajátos nevelési igényú fiatalok, támogatott, mentorált folyamat eredményeképpen, sikeresen tudjanak átkerülni az iskolából a felnôttkori munka világába. Egy keretet ad, amely azt célozza, hogy a munkaerőpiacra történő belépés körülményei minél kedvezőbbek legyenek.

Az Egyéni Átvezetési Terv szorosan kapcsolódik a sajátos nevelési igényú gyermekek és tanulók esetében gyermekkortól alkalmazott Egyéni Fejlesztési Tervhez, de a kettő nem ugyanaz (1. táblázat). Az EÁT része lehet az EFT, de a két dokumentum egymástól függetlenül is értelmezhető.

Az egyéni átvezetési terv jellemzői (European Agency for Development in Special Needs Education, 2005, 26-27. elveire támaszkodva):

- A tankötelezettség megszűnését megelőzően már két vagy három évvel el kell készíteni, annak érdekében, hogy ne az utolsó évben kezdjen el kapkodva felkészülni a fiatal az elótte álló kihívásokra. A tudatos tervezés átláthatóvá és könnyen érthetôvé teszi a fiatal számára a munkaerôpiaci helyzeteket.

- A munkavállalással és a felnőtt élettel kapcsolatos átmenet kérdéseire összpontosít. 
1. táblázat. Az Egyéni Atvezetési Terv (E ÁT) és az Egyéni Fejlesztési Terv (EFT) különbségei. Forrás: a Szerzö́k.

\begin{tabular}{|l|l|}
\hline Egyéni Fejlesztési Terv & Egyéni Átvezetési Terv \\
\hline $\begin{array}{l}\text { Elsósorban a kevésbé jól múködő, fejlesztendő } \\
\text { területek (gyengeségek) és azok fejlesztési mód- } \\
\text { jainak tervezete. }\end{array}$ & $\begin{array}{l}\text { A meglévó egyéni készségek, képességek, kom- } \\
\text { petenciák bemutatásáról szól, az erősségek kieme- } \\
\text { lésével. }\end{array}$ \\
\hline $\begin{array}{l}\text { Folyamatosan készül, három havonta kerül felül- } \\
\text { bírálatra. }\end{array}$ & $\begin{array}{l}\text { Az átmenetek (különös tekintettel az iskola és } \\
\text { munka világába való átmenet) megtervezésére } \\
\text { szolgál. }\end{array}$ \\
\hline A fejlesztendô egyénre koncentrál. & $\begin{array}{l}\text { Az egyén és az átmenetben résztvevők (a család, a } \\
\text { pedagógusok, a gyógypedagógusok, a munkaeró- } \\
\text { piaci szereplők stb.) szerepének, feladatainak, cél- } \\
\text { jainak meghatározása. }\end{array}$ \\
\hline A gyógypedagógus készíti. & $\begin{array}{l}\text { Az átmenetben szerepet játszók közös megálla- } \\
\text { podása, közös tervezése (team-munka), melynek } \\
\text { megalkotásában a legfontosabb szerepe a fiatalnak } \\
\text { van. }\end{array}$ \\
\hline
\end{tabular}

- Megfelelő elkészítése esetén egyfajta személyes portfólió készül el, mely a munkaerőpiacon való elhelyezkedés, szakmakövetelmények mellett a fiatal teljes bemutatásáról szól, tartalmazza a fiatal helyzetére, motivációira, kívánságaira és képességeire vonatkozó információkat is.

- Figyelembe kell venni a munkalehetőségeket és munkakörülményeket, világos elemzést kell adnia a fiatal lehetőségeiről és az ezekből adódó karriertervekről, hogy a valódi munkakörülményekre lehessen felkészíteni a fiatalt.

- A sajátos nevelési igényú fiatalnak aktívan részt kell vennie a saját EÁT-nek az elkészítésében.

- Az EÁT elkészítésébe be kell vonni a fiatal családját, valamint a képzésében részvevő tanárokat, oktatókat, külső szakértőket (szociális munkásokat, közösségi szolgáltatókat, munkaügyi központos szakembereket, EURES- Európai Foglalkoztatási Szolgálat) és a munkáltatókat (munkaadókat, szolgáltatókat).

- Tartalmaznia kell azokat az eszközöket és módszereket, amelyek biztosítják és megkönnyítik az átmenet egyéni folyamatát, és lehetővé kell tennie, hogy a fiatal élni tudjon ezekkel az eszközökkel és módszerekkel.

- Az esélyegyenlőség és esélyteremtés biztositásával kell elkészíteni.

- Az EÁT egy tervezet, melynek rugalmasságát a fiatal egyéni szükségleteinek és motivációinak változásaihoz célszerú igazítani (azaz ezeket figyelembe kell venni és igényváltozás esetén módosítani kell az EÁT-ben leírtakat).

- Biztosítani kell a folyamatos követésvizsgálatát egy erre kijelölt szakember által.

Az egyéni átvezetési terv elkészítése három fő szakaszból áll:

1. szakasz: Információ, megfigyelés és orientáció szakasza - az elókészítés fázisa, azzal a céllal, hogy elősegítsük a sajátos nevelési igényú fiatalok egyéni munkaválasztását és az ehhez szükséges megfelelő helyszín megtalálását.

2. szakasz: Képzés és képesítés szakasza. Ez a fázis a képzés folyamatában a cél eléréséhez vezető konkrét tevékenységekről szól. A képzések és 
képesítések révén a fiatal megfelelő készségekkel, képességekkel, képesítésekkel és kompetenciákkal fog rendelkezni, és lehetôséget kap arra, hogy megszerezze a munkavégzéshez elengedhetetlen megfelelő bizonyítványokat, tanúsítványokat.

3. szakasz: "Felvértezés", munkavállalás és nyomon követés szakasza: a szükséges eredmények szakasza. A végső cél, hogy a fiatal képes legyen az általa választott állást megszerezni és megtartani, mely biztosítja és állandósítja munkaerôpiaci integrációját, ezáltal a társalmi normalizációját, esélyegynlőségét.

$\mathrm{Az}$ egyéni átvezetési tervben többször megjelennek az életpálya-tervezés momentumai, nem csak alkalmi jelleggel, hanem folyamatosan amíg erre a sajátos nevelési igényú fiatalnak szüksége van (akár a felnőtt létre is kiterjeszthetô). Az egyéni átvezetési terv életre szóló segítségét, támogatást nyújt a sajátos nevelési igényú személyek számára, mely nélkül az egész életen át tanulás kiterjesztése az érintettek körére, szinte lehetetlen.

\section{Záró gondolatok}

A sajátos nevelési igényú fiatalok életpályatervezése napjainkban még nem megoldott. A pályára állitás jellemzően egyszeri vagy alkalmi pályaválasztási tanácsadás révén valósul meg, sôt az is gyakran előfordul (különösen az értelmi fogyatékos tanulók esetében), hogy a Pedagógiai Szakszolgálatok egyszerúen kijelölik a tanulók számára legkönnyebben megközelíthető intézményt. A pályaválasztás így az egyéni érdeklődés figyelembe vétele nélkül és családi döntés nélkül valósul meg (holott a tanulói érdeklődés felkeltésének fontosságát már mások is kiemelik Nagy Lehocky, 2008). Szerencsés esetben a tanuló valóban megszereti a választott szakmát, viszont vannak olyanok, akik pont a nem megfeleló beiskolázás miatt vállnak korai iskolaelhagyóvá vagy lemorzsolódnak (Móré és Mező, Katalin, 2016).

A sajátos nevelési igényú fiatalok esetében kevesebb szó esik az élethosszig tartó tanulásról, ez magyarázható a számukra szervezett képzések hiányával és az önképzés, folyamatos képzésbe való bekapcsolódás ösztönzésének elmaradásával is. Ezek a fiatalok többnyire az elsődlegesen elsajátított szakmában szeretnének elhelyezkedni egész életükben, azonban erre már nincs lehetőségük, így gyakran kiszorulnak a munkaerópiacról, marginalizálódnak. A probléma megoldására jó lehetőség az egész életen átíveló életpálya-tervezés, az egyéni átvezetési terv beiktatásával. E tevékenységrendszer alapos átgondolása és kidolgozása a következő feladat a sajátos nevelési igényủ fiatalok és felnőttek egész életen át tartó tanulásának biztosításában.

\section{Irodalom}

2019. évi LXXX. törvény a szakképzésről, hatályba lépés: 2020.01.01.; Web: https://net.jogtar.hu/jogszabaly?docid=a1900 080.tv Letöltés: 2021.11.10.

319/2014. (XII. 13.) Korm. rendelet a Nemzeti Szakképzési és Felnőttképzési Hivatalról (Hatályos: 2017.01.01-től)

A Kormány 12/2020. (II. 7.) Korm. rendelete a szakképzésről szóló törvény végrehajtásáról. Hatályba lépés: 2020.02.15. Web: https://net.jogtar.hu/jogszabaly?docid $=\mathrm{a} 2000$ 012.kor Letöltés: 2021.11.10.

Az Európai Pályaorientációs Szakpolitikai hálózat (ELGPN) Szakszótára. Szerkesztette: Charles Jackson / National Institute for Career Education and Counselling (NICEC), UK, 2011-12

Borbély-Pecze Tibor Bors (2010a): Az életúttámogató pályaorientáció. Doktori értekezés.

Borbély-Pecze Tibor Bors (2017). Az életúttámogató pályaorientáció rendszere változó gazdasági és társadalmi környezetben. Munkaügyi Szemle 60 (1). 11-15.

Borbély-Pecze Tibor Bors (szerk.) (2010b) Az életút-támogató pályaorientáció rendszerének bevezetése. Magyarországon, FSZH, Budapest.

Borbély-Pecze Tibor Bors, Gyöngyösi Katalin, Juhász Ágnes (2013). Az életút-támogató pályaorientáció a köznevelésben 1.rész. Új Pedagógiai Szemle, 2013/5-6.32-49. 
ELGPN (2011): Az élethosszig tartó pályaorientációs szakpolitika fejlesztése: Európai Kézikönyv. European Lifelong Guidance Policy Network (ELGPN). Nemzeti Munkaügyi Hivatal, Budapest. Web: http://www.elgpn.eu/publications/browse-bylanguage/hungarian/az-elethosszig-tartopalyaorientacios-szakpolitika-fejleszteseeuropai-kezikonyv/Letöltés: 2017.11.10.

EU 8448/04 EDUC 89 SOC 179: Strengthening Policies, Systems and Practices in the field of Guidance throughout life in Europe. Web: http://www2.cedefop.europa.eu/etv/Upload/ Projects Networks/Guidance/

Backup/News_Draft_Council_Resolution_16_ April.pdf Letöltés: 2017.11.10.

Európa 2020.Az intelligens, fenntartható és inkluzív növekedés stratégiája. Európai Bizottság, Brüsszel.

European Area of Lifelong Learning, 2001 - A Bizottság közleménye 2001. november 21. az egész életen át tartó tanulás európai térségének megvalósításáról

Garay Magdolna (2013): Az Európai Pályaorientációs Szakpolitikai Hálózat. Életpályatanácsadás, 2. 46-50.

Hegyi-Halmos Nóra (2017). Az életút-támogató pályaorientáció európai uniós ajánlásai és közoktatási gyakorlata néhány tagállamban. In Kereszty Orsolya, Kovács Zsuzsa, Kraiciné Szokoly Mária (Szerk.). A felnőttek tanulásának és képzésének meghatározó trendjei. ELTE Eötvös Kiadó, Budapest.31-48.

Kálmán Anikó (2017). Lifelong Peer Learning New Environments and Scenarios to Build Responsive Systems for Societies. TAMKJOURNAL 2017: Paper Web: http://tamkjournal-en.tamk.fi/lifelong-peerlearning-new-environments-and-scenarios-tobuild-responsive-systems-for-societies/.

Letöltés: 2017.12.16.

Kenderfi Miklós (2011). Tervezési modellek. Szent István Egyetem, Gödöllő.

Memorandum az egész életen át tartó tanuláról (2000). Európai Közösségek Bizottsága, Brüsszel.

Mező Ferenc (2021): Javaslat a pályaorientáció témakörében gyakori fogalmak rendszerezésére.
Különleges Bánásmód, $7 . \quad$ (4). 7-18. doi $\underline{10.18458 / K B .2021 .4 .7}$

Mihály Ildikó (2000): Törekvések az előzetesen megszerzett tudás meg- és elismer(tet)ésére, $U_{j} j$ Pedagógiai Szemle. Web: https://ofi.oh.gov.hu/tudastar/torekvesekelozetesen Letöltés: 2021.11.18.

Móré Mariann; Mező Katalin (2016). Fogyatékosággal élők a tanulástól a munkavállalásig. Különleges Bánásmód 2 : 1. 17-26. doi $\underline{10.18458 / K B .2016 .1 .17}$

Nagy Lehocky Zsuzsa (2008). A tanulói érdéklődés felkeltésének fontossága In Zsófia Bárczi, Ildikó Psenák, Ildikó (Eds). Képrés és gyakorlat = Edukácia a prax : tanulmánykötet, Vančo. - Nitra : UKF, 33-37.

Oktatás és Képzés 2010, az EU Oktatási munkaprogram. Európai Tanács, Brüsszel.

Oktatás és Képzés 2020 stratégiai keretrendszer. Európai Tanács, Brüsszel.

Pályaorientációs Szakpolitikai Hálózat Szakszótára, 2013, p. 13.

Ritoókné Ádám Magda (2008): Pályafejlódési tanácsadás. ELTE Eötvös Kiadó, Budapest.

Soriano Victoria (Ed.) (2005). Egyéni átvezetési tervek. Az iskolából a munka világába való átmenet támogatása. European Agency for Development in Special Needs Education. Web: https://www.european-agency.org/sites $\angle$ default/files/individual-transitionplans itp hu.pdf Letöltés: 2021.10.14.

Stiehm, Judith H., Townsend, Nicholas W. (2002): The U.S. Army War College: Military Education in a Democracy. Temple University Press.

Sultana, Ronald (2011): Learning career management skills in Europe: a critical review. Journal of Education and Work, 1-24. doi $\underline{10.1080 / 13639080.2010 .547846}$

Super, D. E. (1980): A Life-Span, Life-Space Approach to Career Developement. Journal of Vocational Behavior 16, 282-298. doi: 10.1016/0001-8791(80)90056-1

Szilágyi Klára (2000): Munka-, pályatanácsadás mint professzió. Kollégium Kft., Budapest.

Tanítani és tanulni-A tanuló társadalom felé (Fehér könyv)(1995). Európai Bizottság: Budapest, Munkaügyi Minisztérium. 
Vuorikari, Riina (2014): A digitális kompetencia elsajátítása - a 21. századi polgárok elótt álló feladat. http://www. schooleducationgateway.eu/hu/pub/experts/rii na_vuorikari_-_becoming_dig.htm. A kutatási jelentés olvasható: https://ec.europa.eu/digital- single-market/en/news/scoreboard-2014digital-inclusion-and-skills-eu-2014

I1: KSH (2021): Gyorstájékoztató foglalkoztatottság. Web. https://www.ksh.hu/docs/hun/xftp/gyor/fog Lfog2106.html. Letöltés:2021.09.10. 